SAD / JSR

Sosyoloji Araştırmaları Dergisi / Journal of Sociological Research

Cilt / Volume 22 Sayı / Number 1 (Nisan / April 2019) : (254-277)
Araştırma Makelesi / Research Article

Geliş Tarihi / Submited: 02.03.2018

Kabul Tarihi / Accepted: 13.02.2019

\title{
RELINKING THE SOCIAL AND THE POLITICAL: HEGEL, MARX AND THE POLICE AS SOCIALISATION OF THE STATE POWER ${ }^{1,2}$
}

\section{Erol SUBAŞI ${ }^{3}$}

\begin{abstract}
Georg Wilhelm Frederick Hegel has been one of the most influential philosophers of all time. His original philosophical system has been the subject of many studies from various disciplines including philosophy, political science, law, sociology and many more. Despite his long-term popularity, his complex and multidimensional philosophy still allow for further investigations on distinct problems. Although many studies have been carried out on him, only a few writers have been able to draw attention to his ideas concerning police power. Hence, this paper, within the problematic of differentiation of state (political) and bourgeois civil society (social), addresses the question of police in Hegel's thought and the Marx's critique of it. The study argues that the police power appears in Hegel's thought as the socialisation of the state power.
\end{abstract}

Keywords: Hegel, Marx, Police, State, Political, Social

\footnotetext{
${ }^{1}$ This paper was supported by Scientific and Technological Research Council of Turkey (TUB İTAK) a part of 2214-A International Research Fellowship Program (for PhD Students) 2014/1 Grant No:1059B141400383

${ }^{2}$ An earlier version of this paper was presented at the First International Scientific Research Congress on Humanities and Social Sciences, (IBAD 2016), May 19-22, 2016, Madrid, Spain

${ }^{3}$ Dr. Öğr. Üyesi, Recep Tayyip Erdogan Üniversitesi, İIBF, Siyaset Bilimi ve Kamu Yönetimi Bölümü

SAD / JSR

Cilt / Volume 22 Sayı / Number 1 


\section{TOPLUMSALI VE SIYYASALI BİRLEŞTİRMEK: HEGEL, MARX VE DEVLET ERKININ TOPLUMSALLAŞMASI OLARAK POLIS}

\section{ÖZ}

Georg Wilhelm Frederick Hegel tüm zamanların en etkili filozoflarından biridir. Özgün felsefi sistemi felsefe, siyaset bilimi, hukuk ve sosyoloji dahil olmak üzere birçok farklı disiplinde çalışma konusu oldu. Uzun süreli popülerliğine rağmen, karmaşık ve çok boyutlu felsefesi hala farklı sorunlar hakkında daha ileri araştırmalara izin vermektedir. Hegel ile ilgili çok sayıda çalışma yapılmış olsa da sadece birkaç yazar onun polis erki hakkındaki fikirlerine dikkat çekti. Dolayısıyla bu makale, devlet (siyasal) ve burjuva sivil toplum (toplumsal) farklılaşması sorunsalı içinden Hegel'in düşüncesinde polis erki meselesine ve Marx'ın bu konu ile ilgili eleştirilerine değinmektedir. Çalışma, Hegel'in polis erkini devlet erkinin toplumsallaşma anı olarak gördüğünü ileri sürmektedir.

Anahtar Kelimeler: Hegel, Marx, Polis, Siyasal, Toplumsal 


\section{INTRODUCTION}

Hegel is undoubtedly one of the most important philosophical figures in history. His inclusive philosophical legacy leads to various interpretations and movements (i.e. left, centre and right Hegelianism). Hegel is first and foremost a philosopher of change. Although his presentation of history- as the journey of Geist- mostly based on metaphysical arguments, the "rational kernel within the mystical shell", as Marx (1976: 103) puts it, still contains the possibility of a materialist philosophy of history. Even his infamous dialectical reasoning serves to grasp the dynamics of ever-changing history. Hence, one can argue that Hegel's philosophical system, specifically his political philosophy deals with immediate problems-easily identifiable as modern- of his age.

One of the most essential issues Hegel diagnosed was the distinction between state and civil society. Unlike the social contract tradition in 17th and arguably 18th century (especially in Hobbes and Locke) considering state and civil society together and in many cases, interchangeably, Hegel, consciously claimed that, in modern times, state and civil society were separated. Indeed, Hegel was not the only one who regarded civil society "independently" from the state. For instance, Adam Ferguson, one of the preeminent philosophers of the Scottish Enlightenment, and arguably one of the forefathers of sociology, has written a book called "An Essay on the History of Civil Society" (1995) (originally published in 1767). The point that must be underlined is that from the late 18th century on, civil society was started to be understood as a distinct entity from the state. Now, thinkers like Ferguson were able to write the history of civil society without referring to the state. It is not clear that whether Ferguson was aware that his theoretical move had crucial implications in terms of state-civil society relations. Yet, it is evident that Hegel was quite conscious when he was treating civil society as a distinct social sphere from the state. However, he was also aware that it is impossible to think the civil society without the state. 
Hegel's importance lies chiefly in his ability to identify the bourgeois character of the civil society. He explicitly used burgerlische Gesellschaft (bourgeois society) which is not a direct translation of the term civil society as it is commonly used in English. Hegel, obviously, redefined the term by underlining its bourgeois character. By doing this, he replaced civil society into its historico-social context. Furthermore, state and civil society have not just separated; but both have been structurally transformed. Thus, Hegel's project appears to classify those new forms of state and civil society and to relink them.

The crucial point of the argument is that the differentiation of state and civil society is avowedly a modern product of capitalism. Under feudalism, the state and civil society was one and the same because of the fact that state fused every aspect of private lives in civil society. Be it, property, trade, society or man, various social forms were inherently political in the sense that state entirely subsumed civil society. Then, every social form inevitably had a political character. In other words, in the Hegelian conceptual framework, the universal incorporated the particular.

When it comes to capitalism, not just state and civil society, but also social, political and economic spheres are separated. First and foremost,

"capitalism... differs from pre-capitalist forms...by extra-economic modes of surplus extraction, political, legal, or military coercion, traditional bonds or duties, etc., which demand the transfer of surplus labour to a private lord or to state using labour services, rent, tax, and so on." (Wood, 1995: 29).

Hence, the distinguishing characteristic of capitalism was differentiation of economic and political moments. Contrary to pre-capitalist times, in which surplus value was appropriated by the act and/or threat of physical coercion, in capitalism, direct producer, as labour power became free in two senses of the word; free from the means of production and free from the feudal ties. Therefore, in capitalism appropriation of surplus appeared to be non-political and coercion-free. Hence, in capitalism political, social and economic 
spheres were differentiated. Each, respectively, were abandoned to state, bourgeois civil society and market. This disintegration of social totality, in liberal social order, concerned Hegel and urged him to think of this crucial problem. Thus, one may argue that Hegel's Philosophy of Right is the result of this concern.

Whereas this Hegelian problematic of social integration preserved its actuality in post-Hegelian philosophy, political science and sociology. Few studies have pointed out that Hegel's theory of state (see Avineri, 1972) and to a lesser extent his thoughts on the police power (see Neocleous, 2000). Hence,_the primary aim of this paper is to propose a conceptual and theoretical framework for police power based on the Hegelian argument of differentiation of state (political) and bourgeois civil society (social).

The core argument of the study is that, in Hegel's thought, police power appears as one of the mechanisms of the socialisation of the state power relinking the state and bourgeois civil society. Yet, it would be a mistake to conceive the police power as just a neutral mediator; instead as a part of state power, police are employed to shape bourgeois civil society in accordance to ever-changing political ends. Thus, in the Hegelian sense, police power should be taken as a form of state power fabricating consistently social order to overcome the problem of the reunification of state and bourgeois civil society.

The overall structure of the study takes the form of two sections. The first section is concerned with one of the most essential concepts of this study, civil society. The first sub-section of this part deals with the system of needs which is the material base of civil society. The second sub-section, administration of justice, shows that Hegel's bourgeois civil society, is not an entity regulating itself; rather it, despite its unprecedented benefits, systematically produces injustice, inequality and poverty. Therefore, police power is a vital apparatus to administer socio-economic and political problems. The second section includes a discussion on the Hegelian concept of state and differentiation of state and bourgeois civil society. 


\section{CIVIL SOCIETY}

According to Hegel, the fundamental principle of the civil society is the concrete "particular person, as a totality of needs and a mixture of natural necessity and arbitrariness" This is the first principal of civil society. The second one is that each particular person satisfies its needs in relation to other particular persons through the mediation of the form of universality. In other words, individual acts arbitrarily to satisfy his needs. Yet, his arbitrariness or selfishness connects him to the others for a greater or universal good. The individual becomes individual only in his relation to other individuals. Here, Hegel clearly follows the predominant, political-economic interpretation of the "market". Like, Smith, he stresses that being selfish is not actually being selfish because it serves a greater, a universal objective. Civil society as the totality of rational, selfish particular individuals manifests itself as a higher stage of history.

Being intermediate between family and the state and a "self-sufficient entity" civil society is the child of the modern world. In civil society, each and every individual is dependent on others to achieve his/her ends. Therefore, the particular gains a universal form in civil society. Every individual seeking to satisfy its interests -voluntarily or not- contributes to the welfare of others. This is the underlying principle of civil society in which particularity and universality are separated but bound up and conditioned by each other. At this point, Hegel gives the tax example according to which one individual can claim that paying taxes is against his/her particular interests. Yet, in a country where nobody pays his taxes, there can be no particular ends. Therefore, although paying taxes looks like against particular interests, by being in accordance with the universality, it is also indirectly in accordance with the particular ends.

According to Hegel, the civil society contains the following three moments:

A. The mediation of need and the satisfaction of the individual [deseinzelnen] through his work and through the work and satisfaction of the needs of all the others - the system of needs.

SAD / JSR

Cilt / Volume 22 Sayı / Number 1 
$B$. The actuality of the universal of freedom contained therein, the protection of property through the administration of justice.

C. Provisions against the contingency which remains present in the above systems, and care for the particular interest as a common interest, by means of the police and the corporation (Hegel, 1991: 229).

\section{SYSTEM OF NEEDS}

Particularity, as a subjective need, can attain its objectivity only through the satisfaction of the needs by means of external things like property and products, needs and wills of others and activity and work. This is the system of needs. Individual acts and works to satisfy his/her needs, by doing so, s/he helps others to satisfy their personal needs. Therefore, there is a mutual benefit in working and/or appropriating property for every member of the system of needs. This interaction between particular entities, although, prima facie, looks like random and arbitrary; actually, is determined by the universality of the Idea.

Unlike animals, human beings are capable of multiplying both the needs and the different ways of satisfying them. The natural and/or spiritual needs, which are diversified by education, lead human beings into necessary social relationships with others. Thus, in civil society, every individual activity assumes a social character. At this point, one can contend that Hegel's system of needs is a more developed and sophisticated version of the famous formulation of Smith, according to which, individuals satisfy their needs not because of their "benevolence", but because of their own search for satisfaction of their needs. Hegel argues that the system of needs seeming like based on particular individual selfishness actually ends up with a kind of collective benevolence which is definitely compatible with the universality of the GEIST. Therefore, it is the distinctive feature of the modern society. Hegel remarks that the work is the mediation between the "need" and the satisfaction. On the one hand, the work itself satisfies a particular need; on the other hand, it gives necessary means to the worker to satisfy his/her own needs. At this point, it should be noted that 
Hegel acknowledges the Smithian concept of the "division of labour". Like Smith (1981) Hegel recognises the fact that division of labour serves to increase the general wealth of the society. He also argues that; the division of labour deepens the system of needs by making people more dependent on each other. Besides, also like Smith, he warns that the division of labour could turn individuals into the simple machine-like creatures.

In Hegel's words:

In this dependence and reciprocity of work and the satisfaction of needs, subjective selfishness turns into a contribution towards the satisfaction of the needs of everyone else. By a dialectical movement, the particular is mediated by the universal so that each individual, in earning, producing, and enjoying on his own account [für sich], thereby earns and produces for the enjoyment of others (1991: 233).

The individuals have different "basic assets, i.e. Capital" and different skills and abilities to have properties and resources. The latter is partially conditioned by the former. Therefore, in this "sphere of particularity" resources are unequally distributed among individuals. This inequality and differentiation in civil society lead to emerging various socio-economical groups, whose members are similar in terms of "means, varieties of work, modes of satisfaction, and theoretical and practical education" which are called estates (Hegel, 1991: 234). Civil society is divided into different estates. While the family is the primary basis of the state, the estates are the second. It might be said that estates gather individuals having the same socio-economic status in civil society and connect them to the state. At this point, it should be noted that estates are not equivalent to social classes since Hegel already uses the term Klasse, class in different contexts. In Hegel, estates are understood to be mediating mechanisms between civil society and the state. Yet, as Marx points out in Critique of Hegel's Doctrine of the State, [henceforth Critique], they do not fulfil this duty. They are not the moments of politicisation of civil society; rather they are the moments of socialisation of state 
power. In other words, they are the mechanisms of penetration of the state power into the civil society. Nevertheless, the gap between state and civil society can be overcome only by the political participation of the civil society into the legislative power of the state. According to Marx, Hegel's Standes, -inspired by the Standes existed in the mediaeval age- in which there was no gap between the state and civil society-are condemned to be anachronic institutions. Marx argues that particularly with French Revolution, estates as being political expressions of the state and civil society's identity were dissolved into social classes. In other words, the "political" is divided into the political (as state) and the social (as civil society). Meanwhile, civil society itself has been split up into different social classes, and the institutional architecture of the state is simultaneously diversified. Thus, the problem of identity has been deepened and got complicated. What is to be done is to give a political character again to the social one. This would be possible only by the "politicisation" of the social classes which means in toto their political representation in the legislative power. Here, pace Hegel's monarchical position, Marx obviously defends a democratic one. This is the only way of overcoming the separation between the state and civil society. That is the point that Hegel has missed. He has correctly identified the problem of separation of civil society and the state. However, his solution was to build bridges between the state and the civil society, which were the one-way mechanisms of the state's penetration into civil society. Marx argues that Stande, as presented by Hegel, is just the "political illusion" of the civil society. At best, they might be corporational-technical-administrative mechanisms of the state power in the civil society. As noted by Marx, the Stande is the "synthesis of state and civil society" and nothing more. In this regard, Hegel's diagnosis is accurate; yet his treatment is wrong. As for Marx, he also recognises the separation of the state and civil society as a problem to overcome. Nevertheless, his solution is the diametrically opposite one. He proposes the politicisation of the civil society rather than the socialisation of the state power through different institutions.

$\mathrm{SAD} / \mathrm{JSR}$

Cilt / Volume 22 Sayı / Number 1 


\section{ADMINISTRATION OF JUSTICE}

The second moment of civil society is the administration of justice. As we have seen above, the system of needs is possible only by means of the abstract right of property. Every individual has that right. Yet, its actuality is possible only by the protection of property through the administration of justice. The primary instrument of justice is the law. Hegel claims that, in modern times, through the customary rights, the law has reached a certain point of universality and rationality. At the end of this process, abstract right becomes law and only through the law, the property and personality of the individual can be recognised. As Avineri (1972: 136) puts it, "Property is an objectification of the self which raises it from the realm of pure subjectivity into the sphere of external existence." That is to say; the individual can be recognised as "legal subject", vis-à-vis the law, as long as he has property. In other words, having property makes individual a formal-legal subject. Since property and personality are legally-universally recognised in civil society, the crime lost its subjectivity and became a universal issue. In Hegel's (1991: 250) words: a criminal action "may be a danger to society." Once the right of private property has been integrated into the legal code, any attack on the private property assumes not a particular but universal character. It appears as a direct attack to and threatens the security of the civil society.

In civil society, the universality dissolves itself into a diversity of particularities. Thus, particularities should be united once again as the universality. On the one hand, individual freedom, as the particular will is the distinctive feature of civil society. It is compatible with the GEIST. Yet, on the other hand, these different particularities and even different estates pose a problem of social cohesion and/or unity in civil society. Therefore, unity dissolved into different individuals should be reconstructed without abolishing those particularities. As Avineri (1972: 151) puts it, there must be an integration through differentiation in civil society. That is the essence of the Philosophy of Right. How to rebuild a harmonised social order by reuniting the state and the civil society on the one hand and the civil society as a whole which is divided 
into classes, estates and individuals on the other. That is particularly difficult since, as we have seen above, in civil society wealth and properties are unequally allocated. Therefore, in Hegel's (1991: 259) words:

"Justice is a major factor in civil society: good laws will cause the state to flourish, and free ownership is a fundamental condition of its success. However, since I am completely involved in particularity, I have a right to demand that, within this context, my particular welfare should also be promoted. Account should be taken on my welfare, of my particularity, and this is the task of the police and the corporation."

According to Hegel, wealth in civil society is conditioned by the objectives of the system of needs and the subjective, arbitrary will and the particular nature of individuals. The security of persons and property is not enough to reconstruct the unity in civil society. Livelihood and welfare of particular individuals should also be secured as an individual right. For instance, interests of the producers and consumers might be antagonistic. Even if the market is partially capable of overcoming this problem, there should be an "agency which stands above both sides" to "regulate" this antagonistic relation. It seems that Hegel is not entirely convinced by the claim that market is fully operational without state regulation(s). He is worried about the fact that especially "large branches of industry dependent on external circumstances and remote combinations" whose general outcomes are impossible to foresee by individual beings specialised in just one branch and having limited knowledge about market mechanisms.

\section{POLICE}

Hegel claims that the police must mediate between the individual capacity and the universal possibility. Just like Smith's concept of police (see 1982) Hegel's police concept is also much broader than its contemporary meaning. For Hegel (1991: 262): “The police should provide for street-lightning, bridge building, the pricing of daily necessities and public health." Yet, pace Smith (1981) Hegel suggests that it is impossible to think market without regulation and the state. There must be laws and regulations to limit 
the market operations. For instance, Hegel points out that "freedom of trade" should be compatible with the "general good."

At this point, it must be remarked that Hegel considers police and the corporation as the mechanisms of the civil society and not those of the state. Prima facie, it is meaningless in the sense that civil society cannot have such an independent mechanism that would promote the wealth of the poor. Market relations cannot tolerate it. Besides, without the coercive power of the state, it would be entirely useless. So, why does he integrate police and corporation into the civil society? At this point, it might be useful to remember once again Marx's Critique of Hegel according to which, once Hegel has established the state and the civil society as distinct spheres, he could not leave civil society on its own. Marx (1975: 111) remarks that police, judiciary and the administration is not the representatives of the civil society, as claimed by Hegel; on the contrary, they are "representatives" of the state, and their task is to administer the state against civil society. Therefore, the police and/or police power must be understood as a part of the state not that of the civil society. It is a particular way of state's intervention into civil society. Particularly, the police power is the socialisation of the state power. It is one of the attempts to relinking political and social which are separated in a specific historical process by the development of capitalist relations of productions. Thus, I argue that it is a specific form of the state power. It is historically one of the outcomes of the state-civil society distinction. I also contend that this socialisation of the state power is the opposite form of the politicisation of the civil society. As a constant and constitutive power, the police power constantly shapes and reshapes the civil society in such a way that it momentarily oppresses the politicisation of the civil society. However, it is pertinent to note that neither state nor civil society should not be taken as static, abstract-formal and ahistorical categories. Rather, the interpenetrations and interactions between the state and the civil society shape and reshape both. This is not a one-way influence of the state into the civil society; rather state itself, on the one hand, is the outcome of the complex totality of social relations within the civil society and on the other hand; results from the particular form of the state-civil society relations. Therefore, one must 
analyse the state and civil society relation in their socio-political and historical context and both in terms of continuities and discontinuities. In this regard, one should take "the police power" into consideration relationally to the state and civil society. Since I shall focus on the concept of the state in the next section; I shall content myself here with stating these remarks.

While police, secures and protects universal idea as an "external order and arrangement" in the particularity of the civil society, the corporation is the ethical return of particularised universal idea to the civil society. In this sense, the corporation is representational institution engaging particular end with the universality of the civil society. As we have seen above, civil society is composed of different estates. Corporations are representational organs of these estates (agricultural, intermediate and universal). In this regard, the function of the corporations is to defend interests of its members. Yet, its real function is to adapt all the selfishness and ego of the members of a corporation to the universal Idea. While "the family is the first ethical root of the state; corporation is the second and it is based in the civil society" (Hegel, 1991: 272). The former represents the substantial unity while the latter signifies the unity of the particular need and its satisfaction and abstract legal universality; that is to say, the unity of the welfare as a right and the welfare as actualisation. Corporation as such, provide "selfish" individual with a higher, universal context. It is a bridge between particular individuals living in the civil society and the state the highest stage of GEIST in the human history. Corporation as limited and finite finds its infinite and highest end in the state. Therefore, "the sphere of civil society thus passes over into the state"(Hegel, 1991).

Hegel makes a warning about the confusion of the state with civil society and reducing its raison d'être to the protection and/or security of property and personal freedom, eventually "interest of individuals". He underlines that only as a member of the state, an individual can have "objectivity, truth and ethical life" (Hegel, 1991: 276). Thus, Hegel contends that there is a logical fallacy in theorising individual before the concept of the state. However, I argue that there is a circular cause and consequence fallacy in his own 
reasoning. He starts with family and civil society then he reaches to the state. Yet, he claims also that without the state there would be no family and the civil society. As Marx notes in Critique, in Hegel, reasons become conclusions and vice versa. The state is immanent to family and the civil society, but it is also an external necessity. Marx criticises Hegel for giving the theoretical priority to the state and for presenting it ideally-speculatively both as reason and consequence. Pace Hegel, Marx tends to emphasise the role of the family and of the civil society as the preconditions of the state. Hence, while Hegel underlines the primacy of the state; Marx highlights the role of the family and of civil society as the basis of the state. At this point, I claim that neither Hegel in the Philosophy of Right nor Marx in the Critique, despite the fact that they were really close to that point, realized that civil society and the state do exist relationally. That means that they condition and determine each other. I suggest that neither state nor civil society should be taken as ontologically isolated spheres; rather one should investigate their relational crosscutting mechanisms, institutions, and phenomenal forms of interpenetrations to capture the characteristics of state- civil society relationship.

\section{STATE}

Hegel argues that his approach to the state is philosophical rather than historical and/or anthropological. He also contends that Rousseau's claim according to which principal of the state is the will is right. Yet, Rousseau was wrong when he was considering the universal will, only as the sum total of the different individual's wills, which do exist independently from the personal will. Yet, only in the modern state, particular will and the universal will become "one". While particular will is subjective, the universal will is objective. The fusion of particular will and universal will is the rational kernel of the modern state. For instance, in the states of classical antiquity, the universality existed; yet there was no particular will. Particular will was subsumed by the universal one. In other words, there was no civil society but the state. Everything was political, and there was no personal freedom but the will of the sovereign. Nevertheless, in modern times, particular will and universal will independently exist, and they are reunified in the modern 
state. In this respect, the state is the "ethical whole" of the Idea of freedom and its actualisation. It is the consciousness knowing itself. Hegel argues that any discussion of freedom must start with the essence of the state rather than an individual. It is the general scheme of the state and not of a particular one. Since, it is not a "work of art" There might always be "arbitrariness, contingency, and error and bad behaviour" in the state (Hegel, 1991: 279). Nevertheless, in Hegel, the essence of the state remains affirmative.

The Idea of the state:

A. has immediate actuality and is the individual state as a self-related organism - the constitution or constitutional law [inneresStaatsrecht];

B. passes over into the relationship of the individual state to other states - international law [auseresStaatsrecht];

C. is the universal Idea as a genus [Gattung] and as an absolute power in relation to individual states - the spirit which gives itself its actuality in the process of world history (Hegel, 1991: 281).

First, it is pertinent to note that the constitutional monarchy limits Hegel's horizon of his political philosophy. Even, the whole Philosophy of Right might be read as the vindication of the Prussian constitutional monarchy. According to Hegel, the state itself is an organism with its various forms of powers and functions. The constitution is the "starting-point" or the heart of that organism. From there, the idea of the state is differentiated into various powers and functions of the state. By positing state and constitution like this, he attributes the power of the state to itself. There is no attribution to the civil society. Therefore, it seems that state and constitution per se have political power. In that sense, it can be argued that both state and the constitution are reified. There is neither social nor political origin of the state power except the Idea. That means, in Hegel, state power is self-referential. Marx remarks that Hegel's true interest is not the philosophy of right but logic. His method is to derive the empirical fact from the abstract idea or concept. 
However, Marx suggests a diametrically opposite one; to make abstractions through empirical facts. "The concern of philosophy is not the logic of the subject-matter but the subject-matter of logic. Logic does not provide proof of the state, but the state provides proof of logic" (Marx, 1975: 73). In this regard, Hegel's constitution is rational in so far; its elements are compatible with the abstract categories of logic. State's institutional architecture is based on the abstract categories of the Concept. However, as Marx underlines, one should investigate the state's institutions and not the categories of the concept to acquire the knowledge of the state. According to Marx, Hegel's methodology is problematic. His method turns exoteric into the esoteric. The process of acquiring knowledge should be from empirical to theoretical and not the vice versa.

Theorizing constitutional monarchy as the ultimate stop of the GEIST, Hegel had to clarify the role of the monarch in that constitutional monarchy. He attributes three moments to the sovereign; the universality of the constitution and the laws, consultation as the reference of the particular to the universal and the moment of ultimate decision as the self-determination (Hegel, 1991: 313). As can be seen, on the one hand, the sovereign has the universality of the laws and the constitution is represented in his personality. On the other hand, he is the ultimate particular will. Every particular decision of the sovereign is also universal: a "modern" justification of a "pre-modern" power. It appears as a theoretical fait accompli. In this regard, one can contend that Hegel's whole political project is an anachronic effort to put the archaic forms of political power and institutions into a modern socio-political context. I contend that this is an important tension in his political philosophy.

Sovereignty is initially objectivity and then Hegel remarks that sovereignty can exist only as the subjectivity of the Idea. Thus, objectivity is first subjectified and second personified in the monarch. "The personality of the state has actuality only as a person as the monarch"(Hegel, 1991: 317). Why objective sovereignty has to be subjectified in that particular person? As Marx put it, one individual is different from all the others. Why is that? What about the other individuals? What makes special the monarch in terms of GEIST? There 
is no answer for that in Hegel. Marx remarks that Hegel "does not say that the will of the monarch is the final decision, but that the final decision of the will is- the monarch" (1975: 82). Moreover, Hegel differentiates arbitrarily "one individual," i.e. the monarch both from the state and civil society. The source of his power and/or sovereignty is not the other individuals nor civil society but the "Idea" itself. According to Marx, Hegel reificates one individual without even explaining its defining character. Thus, the subject becomes predicate and the predicate becomes subject (Avineri, 1968:15). The source of its power remains unknown since abstract concepts such as Idea or GEIST could not give him that power. The monarch suspends the mid-air. Hegel fails to explain the real socio-political basis of the monarch's power and/or sovereignty. As for Marx, monarch's sovereignty results from the people itself and nowhere else. Idea, GEIST or state cannot give him that power because the state itself is based on the people. Without people, the state would be nothing but an "abstraction" (Marx, 1975: 85). Furthermore, in reality, he does not even possess the sovereignty; rather he just represents the sovereignty of the people.

Since civil society is the sphere of conflict and particular interest, it has to be administered by "higher authorities" to adapt particular interests to the universal ones. This is the immediate concern of the executive power. Even though civil society is divided into estates and corporations whose functions are already similar to those of the executive power; they are not official organs of the state power like bureaucracy. Therefore, estates as mediating mechanisms are immediately subjugated to the executive power of the state. The administration of the police and the judiciary is one of the functions of the executive power even though they are located in the sphere of civil society. The members of the executive power, bureaucrats, are determined according to the principle of the division of labour, and they are expected to be rational and qualified. According to Marx, Hegel fails to explain the very roots of the executive power. He is contented with a formal description of it. Hegel's main concern is the separation of the state from civil society; of particular interests from the universal ones. Therefore, bureaucracy and corporations are based on this separation. While bureaucracy is the "civil society of the state", the corporation is the "state of the civil 
society" (Marx, 1975: 106). By saying this, Marx tries to show that Hegel cannot overcome his own statecivil society dichotomy; rather he establishes various state mechanisms as socialisation of the state power. While they are supposed to be political moments of civil society, they remain administrative moments of the state over civil society. As being "civil society of the state", civil servants belong to the middle class having both political consciousness and a great level of education. Hegel argues that civil servants as being part of the middle class constitute the "mainstay" of the state as far as "integrity and intelligence are concerned". According to Hegel, a developed country needs a developed middle class. That is the problem of Russia for instance. There, there is no middle class but serfs and rulers. Official bodies which constitute the executive power of the state are characterised by the hierarchical internal structure and the division of functions. It seems like that, Hegel considers the executive power of the state purely as an administrativetechnical power over civil society which is exercised through qualified and rational bureaucrats. Therefore, Marx (1975: 114) points out that Hegel establishes "executive as an antithesis of civil society and indeed as a dominant polar opposite. How then does he prove the existence of an identity?" That is indeed a rhetorical question underlining the fact that Hegel cannot establish the unity between the state and civil society.

According to Hegel, legislative power is composed by the constitution, the monarch, the executive power and finally the estates. These are the origins of the legislative power. Hegel's whole formulation is based on the idea of mediation. The constitution, executive power and estates are the mediating mechanisms between the sovereign and the people. Hegel claims that the absence of those mechanisms characterizes despotic state. Nevertheless, that does not mean that Hegel's concern is democratic representation. That is not the case. The only potentially "democratic" elements in the legislative power, i.e. the estates are far from fulfilling that mission. For instance, it is not possible for every member of the estates to become representative of his estate. The representatives of the estates are supposed to be familiar with the universal idea, i.e. the interests of the state and the particular interest. A representative is expected to have certain 
intellectual faculties and physical skills. Besides, the general mission of the representatives of the estates is to reconcile universal interest of the state and particular interests of the different estates. The different estates have different characteristics in terms of representation. As for the universal estate, i.e. the estate of civil servants as a part of the legislative power, becomes a private estate and obtains political significance and function. Since the members of that estate are also the member of the state, Marx claims that, in Hegel, the only moment of unification of the political and the social is realised in that estate, i.e. the bureaucracy. Likewise, because, the bureaucracy is established on the principle of remuneration, the members of that estate are strictly dependant on the state. Another estate namely agricultural, substantial estate, compared to the other, is more independent and better equipped in terms of political instruments. It is independent, because its income is not coming directly from the state but from the land. It's the private property that makes it independent. Every member of this estate, by birthright, has inherited property. Therefore, the wealth makes them to a certain extent political subject. As for bourgeois estate, Hegel attributes it a certain democratic character. The democratic political participation of the individual in the state affairs seems to Hegel is nothing but an abstract and generic effort. Hegel argues that, initially, the individual has to be mediated through his estate. Only by doing so, he would become a universal actor. Besides, Hegel claims that direct participation of each individual to state affairs presupposes the fact that each individual is "expert on such matters". Yet this is not true. Hegel closes the way for the political participation of the masses. Instead, he shows them the sphere of public opinion to express their political opinions. Hence, Hegel has in his mind a corporative representation. That is to say, deputies elected by the members of the civil society, are not the representatives of the individuals but only of the estates. At this point Marx (1975: 188) criticizes Hegel from a democratic standpoint:

As we have seen, the state exists only as a political state. The totality of the political state is the legislature. To take part in the legislature, therefore, is to take part in the political state, it is to prove and realize one's existence as a member of the political state as a member of the state.

$\mathrm{SAD} / \mathrm{JSR}$

Cilt / Volume 22 Sayı / Number 1 
Similarly, Marx argues that one-sided, abstract-legal and/or only social citizenship is not enough to become a "real" member of the state. To become a real member of the state, the citizen has to realise himself politically which is only possible by taking part in the legislature. 


\section{CONCLUSION}

To conclude, it can be said that Hegel's significant contribution to political theory was to identify the state and civil society distinction due to capitalist modernisation. On the one hand, civil society, as burgerliche Gesellschaft- [bourgeois society]- is divided into different classes; on the other hand, simultaneously the institutional architecture of the state is widely diversified. Thus, the problem of unity becomes more and more complex. Once, Hegel problematizes this distinctions and separations as such; he tries to re-establish the unity of the state and civil society through specific mechanisms such as police, judiciary and corporation. Yet, as Marx puts it, these mechanisms created solely an "illusion of unity" and essentially remained as administrative mechanisms of the state vis-à-vis civil society. Following Marx's criticism of Hegel, I claim that by capitalist modernisation, the political unity of state and of civil society, existed in pre-modern ages, is dissolved into political (state) and social (civil society). Hegel's effort is to expand and/or socialize the state power to reconstruct that unity while Marx's solution to that problem is the politicisation of civil society especially by the political participation of the masses into the legislature. In this formulation, the police power appears as a new and historical form of state power, and as a mechanism of socialization of the state power. A mechanism whose general mission is to administer the constant sociopolitical contradictions emerged in civil society. 


\section{ÖZET}

Alman idealizminin önemli temsilcilerinden Georg Wilhelm Friedrich Hegel tarihselci, kapsamlı ve sistematik felsefesi ile önemli bir düşünsel miras bıraktı. Hegel'in tarih felsefesi diyalektik bir form altında, sürekli dönüşen, hareket halinde bir akış fikrine dayanır. Metafizik bir kavram olan Tin'in yolculuğu olarak tasarlanan bu dönüşüm fikri kapitalizmin ortaya çıkması ve Fransız Devrimi gibi gelişmeleri anlamak için felsefi bir arka plan sağlar. Buna göre dönüşüm soyut bir rasyonelliğin kendi kendini gerçekleştirme yolculuğudur.

Hegel'in tarihselci bakış açısı kendinden sonraki birçok düşünürü etkiledi. Tarihsel materyalizmin “tarihsel” sıfatının köklerinin Hegel’ de olduğunu söylemek yanlış olmaz. Marx ve Engels tarihsel devinimi açıklayabilmek için Hegel'in idealist tarih felsefesi içinde materyalist bir imkân gördüler. Bu isimler dışında da birçok düşünür kimi zaman olumlayarak kimi zaman da eleştirel bir tutum takınarak Hegel'e göndermede bulunmak durumunda kaldı. Bunlar arasında Nietzsche, Kierkegaard, Feuerbach, Bauer, Lukacs, Gentile, Croce, Gramsci gibi önemli isimler zikredilebilir. Hegel'in özellikle fenomenoloji, tarih, hukuk, devlet alanlarında yazdıkları çok geniş bir etkiye neden olmuştur. Başta Marksizm olmak üzere, Liberalizm ve Faşizm de ideolojik içeriğindeki birçok temayı Hegel'e referansla açıklamıştır.

Bu bağlamda Hegel felsefesi ile ilgili sayısız çalışmadan söz edilebilirse de Hegel'inki gibi soyutlama düzeyi bir hayli yüksek, kompleks bir felsefi sistemin tam anlamıyla tüketildiğini söylemek mümkün değildir. Her ne kadar Hegel'in devlet felsefesi önemli çalışmalara konu olmuş olsa da aynı şeyi onun polis erki ile ilgili düşünceleri için söylemek mümkün değildir. Hegel'in polis erki ile ilgili düşünceleri sınırlı sayıda çalışma hariç genellikle onun devlet ve hukuk felsefesi ile ilgili görüşlerinin gölgesi altında kalmıştır.

İşte bu çalışma genellikle görmezden gelinen bir kavram olarak Hegel'in polis erki ile ilgili düşüncelerine odaklanmaktadır. Çalışmanın amacı Hegel'in siyasal teoriye en önemli katkılarından biri olan devlet burjuva sivil toplum ayrışması tahlili altında onun polis erkine bakış açısının Marx'ın Hegel'in hukuk 
felsefesi eleştirisi üzerinden değerlendirmektir. Hegel, söz konusu farklılaşmayı önemli bir sosyo-politik sorun olarak tanımladı. Zira devlet ve burjuva sivil toplum ayrışması siyasal özdeşliğin yitimi anlamına gelirken burjuva sivil toplum içindeki bireysel atomizasyon toplumsal özdeşliğin ortadan kalkmas1 anlamına gelmekteydi. Hegel devlet ve burjuva sivil toplumu "kurumsal aracılar" ile birbirine bağlayarak her iki özdeşlik sorununu da çözmeyi amaçladı. Bu kurumsal aracıların en önemlilerinden biri polis erkidir. Bu çalışmanın ana argümanı Marx’ın Hegel eleştirisini de izleyerek Hegel'in polis erkini devlet erkinin bir formu, onun toplumsallaşması olarak kavramsallaştırdığıdır. Dahası polis erki devletin burjuva sivil toplumu sürekli şekillendirmekte kullandığg bir müdahale mekanizması haline gelmektedir. 


\section{REFERENCES}

Avineri, S. (1968). The Social and Political Thought of Karl Marx. London: Cambridge University Press.

Avineri, S. (1972). Hegel's Theory of the Modern State. Cambridge: Cambridge University Press.

Ferguson, A. (1995). An Essay on The History of Civil Society. F. Oz-Salzberger (Ed.). Cambridge: Cambridge University Press.

Hegel, G. W. F. (1991). Elements of the Philosophy of Right. A. W. Wood (Ed.), H. B. Nisbet (Çev.). Cambridge: Cambridge University Press.

Marx, K. (1975). Early Writings. R. Livingstone and G. Benton (Çev.). New York: Penguin.

Marx, K. (1976). Capital: A Critique of Political Economy Volume One. B. Fowkes (Çev.). London: Penguin Books.

Neocleous, M. (2000). The Fabrication of Social Order: A Critical Theory of Police Power. London: Pluto Press.

Smith, A. (1981). An Inquiry into the Nature and Causes of the Wealth of Nations. R. H. Campbell, A. S. Skinner, \& W. B. Todd (Ed.) (C. I). Indianapolis: LibertyPress.

Smith, A. (1982). Lectures on Jurisprudence. R. L. Meek, D. D. Raphael, \& P. G. Stein (Ed.). Indianapolis: Liberty Fund.

Wood, E. (1995). Democracy Against Capitalism. Cambridge: Cambridge University Press. 